\title{
Narlı Ovası Topraklarının Ağır Metal Kapsamı Üzerine Çimento Fabrikası Baca Tozlarının Etkileri
}

\author{
Kadir Saltalı1 Recep Gündoğan² Ömer Faruk Demir' Zekeriya Kara' Tuğrul Yakupoğlu³ \\ Hüseyin Dikici' Kadir Yılmaz' *
}

\begin{abstract}
'KSÜ, Ziraat Fak., Toprak Bilimi ve Bitki Besleme Böl., Avșar Kampüsü, 46100, Kahramanmaraș
${ }^{2}$ Harran Üni., Ziraat Fak., Toprak Bilimi ve Bitki Besleme Bölümü, Osmanbey Kampüsü, 63100, Șanlıurfa

${ }^{3}$ Bozok Üni., Ziraat Fak., Toprak Bilimi ve Bitki Besleme Böl., Erdoğan Akdağ Kampüsü, 66000, Yozgat
\end{abstract}

*Sorumlu yazar e-mail (Corresponding author e-mail): kyilmaz@ksu.edu.tr

Geliș tarihi (Received) : 17.08.2017

Kabul tarihi (Accepted): 15.09.2017

DOI : $10.21657 /$ topraksu.410113

\section{Öz}

Bu çalıșmada, Kahramanmaraș Narlı Ovası topraklarında çimento fabrikası baca tozlarının toprak özellikleri üzerine etkileri araștırımıștır. Bu amaçla, fabrika içerisinden çimento yapımında kullanılan 10 adet ham materyal ve çimento fabrikası etrafından 37 farklı noktadan toprak örnekleri alınmıștır. Toprak örneklerinde kirlilik gösterge parametreleri listesinde (NACE Kodu 2351) verilen ağır metallerle (kadmiyum (Cd), krom (Cr), bakır (Cu), nikel (Ni), kurșun (Pb), çinko (Zn) ve arsenik (As)) birlikte kükürtün (S) toplam içerikleri belirlenmiștir. Elde edilen verilerden yönetmelikte vurgulanan referans değerden sapma değerleri ve katılım-kayıp oranları ( $\beta$ faktörleri) her element için hesaplanmıș ve değerlendirilmiștir. Referans değerden sapma ve katılım-kayıp oranları ( $\beta$ değerlerinin) verilerinin genellikle 1 civarında olduğu, çimento fabrikasına yakınlık ve uzaklığa bağlı olarak bir değișkenlik olmadığı saptanmıștır. Ayrıca, ölçülen parametrelerin ana materyalle ilișkili Ni ve Cr haricinde kirlilik sınır değerlerini geçmediği tespit edilmiștir.

Anahtar Kelimeler: Ağır Metal, Katııım-Kayıp Oranları, Narlı Ovası, Toprak Kirliliği

\section{Chimney Dusts Effects of Cement Factory on Heavy Metal Contents of Narlı Plain's Soils}

\begin{abstract}
In this study, effects of cement factory chimney dusts on soil properties were investigated in Kahramanmaraș Narlı Plain soils. For this purpose, 10 raw materials which are used for producing cement and 37 soil samples around the factory were collected. Total concentrations of heavy metals (cadmium $(\mathrm{Cd})$, chromium $(\mathrm{Cr})$, copper $(\mathrm{Cu})$, nickel $(\mathrm{Ni})$, lead $(\mathrm{Pb})$, zinc $(\mathrm{Zn})$, and arsenic (As)) which are listed as pollutant indicator parameters (NACE code 2351) and sulfur (S) were determined in the soil samples. Increment-decrement ratios ( $\beta$ factors) and deviations from reference values were calculated and evaluated for each element measured. It was determined that increment-decrement ratios ( $\beta$ factors) and deviations from reference values were generally around 1 , and these values were not dependent on distance from the factory. It was also found that the measured attributes do not exceed the pollution limits except $\mathrm{Ni}$ and $\mathrm{Cr}$, which were related to the parent material.
\end{abstract}

Key words: Heavy Metals, Increment-Decrement Ratios, Narlı Plain, Soil Pollution 


\section{Giriș}

Ekolojik anlamda ağır metal kavramı, kirlenme ve toksisite bakımından bir yan anlam olarak kullanılmakta ve çoğunlukla atom numarası 20'nin üzerinde olan metaller bu kapsama girmektedir (Haktanır ve Arcak, 1998). Yakın zamana kadar, ağır metallerin büyük kısmı, fosil enerji kaynakları ve yenilenemeyen ham maddeler olarak yer kürenin derinliklerinde inert durumda kalmıștır. Ancak, endüstriyel kullanımın gereksindiği ham madde talebi artıkça, bu maddelerin kullanımı ve dolayısı ile ağır metallerin ekstraksiyonu artmıș ve bu maddeler doğrudan yayılma olanağı bulmușlardır (Gül, 2011 ).

Tarım arazilerinde en önemli kirlilik kaynaklarından birisi ağır metal kirliliği olduğu bilinmektedir. Ağır metal kirliliğine neden olan önemli faktörler ise șehirsel atıkların ve arıtma çamurlarının arazilere kontrolsüz uygulanması, sanayi kaynaklı katı ve sıvı atıkların tarımsal alanlarda kullanımı ile hatalı kullanılan tarım ilaçları ve gübreler olarak bilinmektedir. Bununla birlikte, farklı ülkelerde yapılan araștırmalarda çimento fabrikalarının da tarım topraklarında kirliliğe neden olduğu rapor edilmiștir (Khashman ve Shawabkeh, 2006). Bu nedenle fabrika bacalarından salınan tozların topraklar üzerindeki etkileri araștırma konusu olagelmiștir. Abeln (1993), çimento fırını tozlarını, fabrika baca tozlarının birikmesiyle olușan tanecikli yapıda, birikmiș cüruf parçaçıkları, reaksiyona girmemiș ve kısmen yanmıș ham materyaller ve alkali sülfatlar, halitler ve diğer uçucu yakıt küllerinden olușan bir malzeme olarak tanımlamıștır. Mandal ve Voutchkov (2011), çimento fabrikasından çıkan atıkların, çevresinde yer alan toprakların element içeriğine etkisi üzerine yaptıkları bir çalıșmada mesafeye bağlı olarak fabrika çevresinden alınan toprakların kurșun (Pb), çinko (Zn), krom (Cr), kadmiyum (Cd), vanadyum $(V)$ ve cIva $(\mathrm{Hg})$ içeriklerinin artıș gösterdiğini, en yüksek artıșın fabrikaya en yakın mesafelerde olduğunu belirtmișlerdir. Ișıklı vd. (2006)'de, benzer bir çalıșmada çimento fabrikasına yakın olan alanlarda topraktaki Cd konsantrasyonunun yüksek olduğunu, fabrikadan uzaklașıldığında ise $\mathrm{Cd}$ konsantrasyonunun azaldığını rapor etmișlerdir. Diğer yandan Khamparia vd. (2012)'i, çimento fabrikasından çıkan tozların toprak kirletici etkisinin bir kilometre uzaklığa kadar belirgin olmakla birlikte ikinci kilometrede de etkisini gösterdiğini bildirmiștir.
Çimento fabrikasından çıkan tozların rüzgarın hızı ve yönüne bağlı olarak 5-7 km uzaklıkta toprakta, kalsiyum oksit (CaO), kalsiyum karbonat (CaCO3) ile mangan (Mn), Cu, Zn ve Pb miktarının artıșına neden olduğu rapor edilmiștir (Maina vd., 2013). Farklı bir çalıșmada ise Büyükçekmece gölü havzasında yüksek oranda $\mathrm{Cr}$ belirlenmiș ve Cr'un kaynağı olarak çimento fabrikasının olduğu ileri sürülmüștür (Karaca vd., 2006). Uysal vd. (2006)' ine göre ise, çimento fabrikalarının yer seçiminde bölgenin meteorolojik özelliklerini dikkate almadan kurulmasının çevredeki ekosistemin dengesini bozduğu ve atmosfere bırakılan atıkların hava, su ve toprak kalitesini önemli ölçüde etkilediği bildirilmiștir.

Bu araștırmanın amacı, Narlı Ovası'nda faaliyet gösteren çimento fabrikasından atmosfere salınan baca tozlarının bölge toprakları üzerine etkilerini, çimento yapımında kullanılan ham materyaller ve alandan alınan toprak örneklerinde ölçülen toplam ağır metal ve S konsantrasyonları kullanarak belirlemektir.

\section{Materyal ve Yöntem \\ Çalıșma Alanının Özellikleri}

Çalıșma alanı Kahramanmaraș il merkezinin yaklașık 30 km güneydoğusunda yer almaktadır. Bu alan Narlı Ovası'nda faaliyet gösteren çimento fabrikasının bulunduğu alanı ve çevresini de kapsamaktadır. Örnek alınan noktaların ve çalıșma alanının gösterimi Șekil l'de verilmiștir.

Yüz ölçümü yaklașık 26500 ha olan ova, Akdeniz iklimi ile karasal iklimin geçiș kușağında yer alıp bozulmuș Akdeniz iklimi özelliği tașımaktadır (Korkmaz, 2001). Toprak nem rejimi

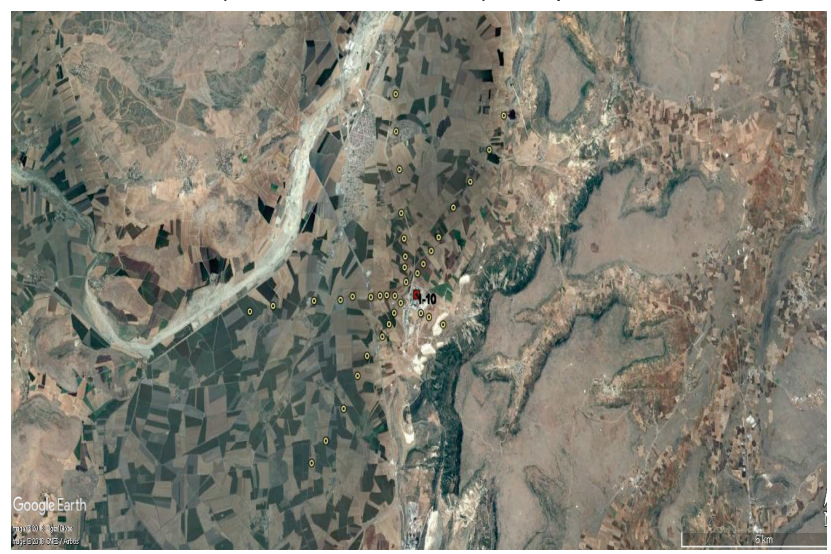

Șekil 1. Çalıșma Alanı ve Toprak Örneklerinin Alındığı Noktalar Figure 1. Research Area and Points of Soil Samples 
Çizelge 1. Meteorolojik Veri Grafiği-Kahramanmaraș lli Aylık Ortalama Sıcaklık (K.Maraș Meteoroloji İstasyonu Müdürlüğü, 2018b) Table 1. Meteorological Data Graphic-Kahramanmaras City Monthly Average of Heat (Directorate of K.Maras Meteorology Station) Aylık Toplam Yağıș Miktarı (mm)

\begin{tabular}{ccccccccccccc}
\hline \multicolumn{1}{l}{ İstasyon Adl: Kahramanmaraș } \\
\hline YIl/Ay & 1 & 2 & 3 & 4 & 5 & 6 & 7 & 8 & 9 & 10 & 11 & 12 \\
2010 & 288.6 & 63.4 & 46.6 & 94 & 14 & 1.8 & 1.6 & 0.0 & 1.4 & 37.6 & 0.0 & 166.0 \\
2011 & 141 & 103.4 & 89.4 & 151.8 & 60.8 & 9.2 & 0.0 & 0.0 & 4.2 & 19.8 & 90.6 & 83.8 \\
2012 & 317.0 & 210.8 & 61.8 & 42.8 & 13.8 & 7.6 & 1.6 & 0.0 & 0.0 & 20.6 & 49.2 & 1.0 \\
2013 & 13.2 & 104.8 & 57.6 & 69.2 & 30.4 & 34.6 & 0.0 & 0.0 & 38.4 & 37.0 & 29.4 & 49.8 \\
\hline
\end{tabular}

KAHRAMANMARAS İLİ HAKİM RÜZGAR YÖNÜ(1960-2016)

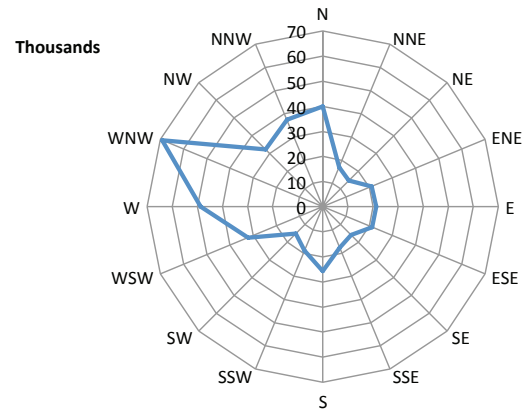

Șekil 2. Meteorolojik Veri Grafiği-Kahramanmaraș ili Uzun Yıllara Göre Hakim Rüzgar Yönü (K.Maras Meteoroloji İstasyonu Müdürlüğü, 2018al

Figure 2. Meteorological Data Graphic-Kahramanmaras City Dominant Wind Direction According to the Long Term (Directorate of K.Maras Meteorology Station)

Xeric, sıcaklık rejimi ise Thermic'dir. Aluviyal ve koluviyal topraklardan olușan ovada Fluvaquents ve Xerofluvents büyük grupları yaygındır (Gündoğan, 1998). Çalıșma alanının rüzgar özellikleri değerlendirildiğinde Kahramanmaraș'ta esme sayısı 3619 olan WNW yönlü rüzgar hakimdir. Bunu 2758 esme sayısı ile NNW yönlü hakim rüzgar takip eder. Yıl içinde esme sayısı en az olan rüzgar yönü SSE'dir. Kıșın hakim rüzgar yönü kuzeydir. İlkbahar, yaz ve sonbaharda ise WNW'dir (Șekil 2). Bölgenin aylık toplam yağıș miktarları incelendiğinde ise en çok yağıșın kıș mevsiminde, en az yağıșın ise yaz mevsiminde düștüğü görülmektedir (Çizelge 1).

\section{Materyal}

Çalıșma alanından, genellikle tarım alanlarının bulunduğu kuzey (8), kuzeydoğu (8), batı (9) ve güneybatı (9) ve doğu (3) yönlerinden yüzey $(0 / 30 \mathrm{~cm})$ ve yüzey altı toprak derinliklerinden (30/60 cm) koordinatlı olarak 37 farklı noktadan alınan toprak örnekleri ile fabrika içerisinden alınan ve çimento yapımında kullanılan 10 adet ham madde numunesi (kalker (1), marn (2), kumtașı (3), demir cevheri (4), alçı tașı (5), volkanik tüf (6), traș (7), kömür (8), linyit (9), petrokok (10)) olmak üzere toplam 47 adet örnek çalıșma materyali olarak kullanılmıștır.

\section{Yöntem}

Alandanalınantoprakörnekleriodasıcaklığında kurutulduktan sonra tahta tokmaklarla dövülerek 2 mm'lik elekten geçirilmiștir. Analize hazır hale getirilen örneklerde, öncelikle pH (Black, 1965), tuz (Richards, 1954), kireç (Gülçur, 1974) ölçümleri gerçekleștirilmiștir. Daha sonra toprak örnekleri, mikro dalga numune hazırlama setinde asit karıșımları ile $18 \mathrm{ml} \mathrm{HNO}, 5 \mathrm{ml} \mathrm{HCl}, 1 \mathrm{ml}$ HF ve $5 \mathrm{ml} \mathrm{H3BO3} \mathrm{karıșımı)} \mathrm{yakılarak} \mathrm{elementel}$ ölçümler için hazır hale getirilmiștir (Hossner, 1996). Bu örneklerde, Çimento İmalatı Yapılan Endüstriyel Faaliyet Alanlarında Faaliyete Özel Kirletici Gösterge Parametreleri listesinde (NACE Kodu 2351) verilen ağır metallerin $(\mathrm{Cd}, \mathrm{Cr}, \mathrm{Cu}$, $\mathrm{Ni}, \mathrm{Pb}, \mathrm{Zn}$ ve As) toplam konsantrasyonları ICPOES cihazında, $S$ elementi ise X-Ray Floresans (XRF) ile belirlenmiștir (Somogyi vd., 1997). Fabrikadan alınan ham maddeler ise tahta tokmalarla dövülerek toz haline getirildikten sonra yukarıda belirtildiği gibi asit karıșımları ile çözülerek analize hazırlanmıș ve X-Ray Floresans (XRF) spektroskopisinde elementel içerikleri (kalsiyum (Ca), silisyum (Si), demir (Fe), alüminyum (Al), sodyum (Na), magnezyum (Mg), titanyum (Ti), fosfor (P), potasyum (K), strontiyum $(\mathrm{Sr})$, zirkonyum $(\mathrm{Zr})$, rubidyum (Rb), baryum (Ba), molibden (Mo), vanadyum (V), kobalt (Co), itriyum $(\mathrm{Y})$, niyobyum $(\mathrm{ND})$, seryum $(\mathrm{Ce})$, brom $(\mathrm{Br})$, holmiyum $(\mathrm{Ho})$, klor $(\mathrm{Cl})$, rutenyum (Ru), $\mathrm{Pb}$, $\mathrm{Zn}, \mathrm{Cu}, \mathrm{Mn}, \mathrm{Cr}$, As ve S) belirlenmiștir (Çizelge 2). 
Çizelge 2. Fabrikada Kullanılan Ham Maddelerin Toplam Kimyasal Analiz Sonuçları

Table 2. Total Chemical Analyses of Raw Materials which are used in Factory

\begin{tabular}{|c|c|c|c|c|c|c|c|c|c|c|c|c|c|c|c|c|}
\hline $\begin{array}{c}\text { Örnek } \\
\text { No }\end{array}$ & $\mathrm{Ca}$ & Si & $\mathrm{Fe}$ & $S$ & $\mathrm{Al}$ & $\mathrm{Na}$ & $\mathrm{Mg}$ & $\mathrm{Ti}$ & $\mathrm{Cr}$ & $\mathrm{P}$ & K & $\mathrm{Mn}$ & $\mathrm{Pb}$ & $\mathrm{Sr}$ & $\mathrm{Zr}$ & $\mathrm{Zn}$ \\
\hline \multicolumn{13}{|c|}{$\%$} & \multicolumn{4}{|c|}{$\mathrm{mg} \mathrm{kg}^{-1}$} \\
\hline 1 & 61.64 & 1.67 & 3.27 & 0.02 & 0.61 & $-*$ & 0.86 & 0.08 & 1.20 & 0.09 & 0.08 & 0.06 & $-*$ & 338.2 & 0.9 & 51.4 \\
\hline 2 & 15.96 & 17.92 & 8.09 & 0.16 & 6.63 & 0.46 & 4.12 & 0.55 & 0.41 & 0.20 & 1.68 & 0.13 & $-*$ & 591.9 & 364.8 & 160.6 \\
\hline 3 & 1.14 & 24.71 & 6.73 & 0.13 & 11.63 & 0.19 & 0.63 & 1.29 & 0.38 & 0.26 & 4.04 & 0.05 & -* & 0.0 & 1003.2 & 50.6 \\
\hline 4 & 1.58 & 19.84 & 13.00 & 0.02 & 12.53 & 0.23 & 0.78 & 0.68 & 0.32 & 0.59 & 3.92 & 0.04 & 62.2 & 169.1 & 547.2 & 160.6 \\
\hline 5 & 30.74 & 1.54 & 2.56 & 16.52 & 0.42 & $-*$ & 2.65 & 0.05 & 1.05 & 0.11 & 0.12 & 0.05 & $-*$ & 10062.2 & $-*$ & $-*$ \\
\hline 6 & 7.77 & 17.35 & 12.43 & 0.19 & 7.78 & 1.91 & 3.65 & 1.57 & 0.68 & 0.35 & 1.20 & 0.19 & $-*$ & 1099.2 & 456.0 & 160.6 \\
\hline 7 & 7.63 & 24.04 & 5.60 & 0.18 & 7.39 & 0.95 & 2.64 & 0.59 & 0.64 & 0.24 & 2.29 & 0.08 & $-*$ & 1014.7 & 182.4 & 80.3 \\
\hline 8 & 3.86 & 17.44 & 10.31 & 3.72 & 10.31 & 0.20 & 0.83 & 0.88 & 1.31 & 0.57 & 2.68 & 0.13 & $-*$ & 930.1 & 0.0 & 401.6 \\
\hline 9 & 19.06 & 11.74 & 9.86 & 4.95 & 5.46 & 0.09 & 1.85 & 0.77 & 1.11 & 0.40 & 0.90 & 0.13 & $-*$ & $-*$ & 182.4 & 562.2 \\
\hline 10 & 0.86 & 1.02 & 1.87 & 34.36 & 0.39 & 0.28 & 0.22 & 0.04 & $-*$ & 0.25 & 0.07 & 0.05 & $-*$ & $-*$ & $-*$ & 321.3 \\
\hline
\end{tabular}

Çizelge 2. (devam). Fabrikada Kullanılan Ham Maddelerin Toplam Kimyasal Analiz Sonuçları

Table 2. (Continue). Total Chemical Analyses of Raw Materials which are used in Factory

\begin{tabular}{|c|c|c|c|c|c|c|c|c|c|c|c|c|c|c|}
\hline $\begin{array}{c}\text { Örnek } \\
\text { No }\end{array}$ & $\mathrm{Cu}$ & $\mathrm{Rb}$ & Ba & V & $\mathrm{Co}$ & Y & As & $\mathrm{Nb}$ & $\mathrm{Ce}$ & $\mathrm{Br}$ & $\mathrm{Ho}$ & $\mathrm{Cl}$ & Mo & $\mathrm{Ru}$ \\
\hline \multicolumn{15}{|c|}{$\mathrm{mg} \mathrm{kg}^{-1}$} \\
\hline 1 & 79.8 & -nd & $-*$ & $-*$ & $-*$ & $-*$ & $-*$ & $-*$ & $-*$ & $-*$ & -* & 200 & $-*$ & $-*$ \\
\hline 2 & 79.8 & 84.1 & $-*$ & 175.82 & $-*$ & $-*$ & $-*$ & $-*$ & $-*$ & $-*$ & -* & $-*$ & $-*$ & $-*$ \\
\hline 3 & 79.8 & 182.9 & 1791.2 & $-*$ & $-*$ & $-*$ & 21.2 & 42.7 & $-*$ & $-*$ & -* & 200 & $-*$ & $-*$ \\
\hline 4 & 63.9 & 182.9 & 716.5 & $-*$ & $-*$ & 157.5 & 151.5 & 21.7 & $-*$ & $-*$ & -* & $-*$ & $-*$ & $-*$ \\
\hline 5 & 69.5 & $-*$ & $-*$ & $-*$ & $-*$ & $-*$ & $-*$ & $-*$ & $-*$ & $-*$ & -* & $-*$ & $-*$ & $-*$ \\
\hline 6 & 159.8 & 28.4 & $-*$ & $-*$ & $-*$ & $-*$ & $-*$ & 63.6 & $-*$ & $-*$ & -* & 400 & $-*$ & $-*$ \\
\hline 7 & 51.1 & 182.9 & 537.4 & $-*$ & $-*$ & -* & $-*$ & $-*$ & $-*$ & $-*$ & $-^{*}$ & 400 & $-*$ & $-*$ \\
\hline 8 & 399.4 & 274.3 & 3851.2 & 307.7 & $-*$ & $-*$ & 75.8 & $-*$ & $-*$ & $-*$ & -* & 2400 & 266.57 & 300.00 \\
\hline 9 & 159.8 & 91.4 & 7881.5 & 527.5 & $-*$ & -* & 75.8 & $-*$ & $-*$ & 100.0 & -* & 400 & $-*$ & $-*$ \\
\hline 10 & $-*$ & $-*$ & $-^{*}$ & 15692.3 & $-^{*}$ & $-*$ & $-^{*}$ & $-^{*}$ & $-*$ & $-*$ & -* & 7700 & 333.22 & $-^{*}$ \\
\hline
\end{tabular}

*: Tespit edilememiștir

\section{Kirlilik Gösterge Parametre Değerlerinin Referans Değerlerle Karșılaștırılması}

Fabrika sahasından farklı yönlerden ve koordinatlardan toprakların üst ve alt katmanlarından alınan toprak örneklerinde, ilgili yönetmelikte verilen kirlilik gösterge parametre değerleri belirlenmiștir. Fabrikaya uzaklığı 2-6 km olan üç farkı toprağın ortalaması referans değer olarak alınmıș ve bu değerler fabrika çevresinden alınan örnekler ile karșılaștırılarak,
Referans Değerden Sapma verileri Toprak Kirliliğinin Kontrolü ve Noktasal Kaynaklı Kirlenmiș Sahalara Dair Yönetmelikte verilen eșitlik 1 'e göre bulunmuștur. Referans noktalarının seçiminde, hakim rüzgar yönünün etki alanı dıșında olması gözetilmiștir. Bu anlamda, WNW hakim rüzgar yönü etki alanı dıșında bulunan alandan üç farklı noktadan alınan örnekler referans olarak kullanılmıștır. Sapma verilerinin değerlendirmesi ilgili yönetmelikte belirtilen ve așağıda verilen temel kriterlere göre yapılımıștır (Anonim, 2010). 
Sapma=Maksimum Ölçüm Değeri $\left(O ̈ D_{\max } / /\right.$ Referans Değeri (RD) Eșitlik; (1)

Kriter Değerlendirme

$\leq 1$ Takip gerektirmeyen saha (kirlenmemiș saha)

>1 İkinci așama değerlendirme sürecine tabi takip gerektiren saha

>25 Bakanlıkça belirlenen süreç uyarınca temizlenmesi gereken kirlenmiș saha

\section{Katılım-KayıpFaktörlerinin ( $\beta$ ) Hesaplanması}

XRF ve ICP-OES analizleri sonucunda elde edilen verilerden, elementlerin moleküller oranları kullanılarak katılım-kayıp faktörleri ( $\beta$ ) hesaplanmıștır (Jenny, 1967). Katılım-kayıp faktörü $(\beta)$, toprak içerisindeki elementel değișkenliğin doğal olarak mı yoksa dıșardan katıım ile oluștuğunun belirlenmesinde temel kriterlerden biridir. Alüminyum (Al) elementi pH 5-8.5 değerleri arasında toprakta çözünmez konumda olduğundan araștırmacılar tarafindan referans element olarak kabul edilmektedir. $\mathrm{Bu} \mathrm{pH}$ aralığında, toprakta $\mathrm{Al}_{2} \mathrm{O}_{3}$ 'un hareketinin az olduğu kabul edilmektedir (Sayın, 2011). Bu nedenle, alanda diğer elementlerin hareketliliğini ve üst toprak katmanına herhangi bir elementin katılımının olup olmadığını belirlemek için bu araștırmada Al referans element olarak kullanılmıștır. Alanda katııım-kayıp faktörleri (ß), ölçülen toplam konsantrasyonlardan hareketle, yüzey katmanı moleküler oranının, yüzey altı katmanı moleküler oranına bölünmesi ile eșitlik 2'de belirtildiği gibi hesaplanmıștır (Sayın, 2011).

$\beta$ =yüzey katmanı moleküler oranı / yüzey altı katmanı moleküler oranı Eșitlik; (2)

Katılım-kayıp süreçlerinin yorumlanmasında, $\beta$ < 1 toprak olușum süreci içerisinde çeșitli faktörlerin etkisine bağlı olarak elementin önemli oranda hareket ettiğini, $\beta=1$ toprakta bir kayıp ya da katııımın olmadığı ve $\beta>1$ ise toprağa dıșarıdan bir katııımın olduğunu göstermektedir (YıImaz, 1990 ).

\section{İstatistiksel Analizler}

Yüzey $(0 / 30 \mathrm{~cm}$ ) veyüzey altı (30/60) derinlikten alınan toprak örneklerinde araștırılan elementlerin karșılaștırılması eșli t testi ile toprak örneklerinin mesafe ( 0-1000 m), (1000-2000 m) ve (20006000 m) ile değișimi Pearson korelasyon katsayısı ile SPSS'de analiz edilmiștir (Efe vd., 2000).

\section{Bulgular ve Tartıșma}

Çalıșma alanından, çimento fabrikasına uzaklık ve toprak derinliği esas alınarak alınan örneklerin bazı genel kimyasal analiz sonuçlarına ait en düșük, en yüksek ve ortalama değerler Çizelge 3' de verilmiștir.

Çizelge 3'de görüldüğü gibi araștırma alanı topraklarının pH'ları 7.76-8.35 arasında değișmekte olup hafif alkalin karakterlidir. EC değerleri $1.59-4.11$ dS $\mathrm{m}^{-1}$ arasında değișmekte olup tuzluluk problemi genellikle yoktur. Ancak bir noktada, toprakta tuzluluk $4 \mathrm{dS} \mathrm{m}^{-1}$ nin üzerinde olup hafif tuzluluk problemi görülmektedir. Toprakların kireç içerikleri ise oldukça değișken olup \% 3.91- 27.5 (kireçli - çok kireçli) arasında değișmektedir.

Toprakların Ağır Metal Konsantrasyonunda Sapma Değerleri ve Katılım-Kayıp Oranı ( $\beta$ faktörü) Bakımından Değerlendirilmesi ve Ağır Metal Konsantrasyonlarının Mesafe ile Değișimi

Çimento fabrikası çevresinden alınan topraklarda toprakların farklı derinliklerinde toplam metal konsantrasyonları $\left(\mathrm{mg} \mathrm{kg}^{-1}\right)$, ölçüm değerlerinin referans değerlerle karșılaștırılması ile elde edilen sapma değerleri, katıım-kayıp oranı ilișkilerinden elde edilen $\beta$ değerleri ve ağır metal konsantrasyonları ve mesafe arasındaki ilișkiler Çizelge 4'de verilmiștir.

Kadmiyum: Araștırma alanı topraklarının her iki toprak derinliğinde toplam Cd içerikleri 0.6 $-1.1 \mathrm{mg} \mathrm{kg}^{-1}$ arasında değișmektedir. Topraklarda ölçüm değerlerinin referans değerlerle

Çizelge 3. Toprak Örneklerinin Bazı Genel Kimyasal Özellikleri Table 3. Some General Properties of Soil Samples

\begin{tabular}{cccccccc}
\hline $\begin{array}{c}\text { Üst } \\
\text { Toprak }\end{array}$ & $\mathrm{pH}$ & $\begin{array}{c}\mathrm{EC} \\
\mathrm{dS} \mathrm{m} \mathrm{m}^{-1}\end{array}$ & $\begin{array}{c}\mathrm{CaCO}_{3} \\
\%\end{array}$ & Alt Toprak & $\mathrm{pH}$ & $\begin{array}{c}\mathrm{EC} \\
\mathrm{dS} \mathrm{m} \mathrm{m}^{-1}\end{array}$ & $\begin{array}{c}\mathrm{CaCO}_{3} \\
\%\end{array}$ \\
\hline En Küçük & 7.76 & 1.59 & 3.91 & En Küçük & 7.80 & 1.85 & 4.21 \\
En Büyük & 8.25 & 4.78 & 27.4 & En büyük & 8.35 & 4.02 & 27.5 \\
Ortalama & 8.03 & 2.71 & 17.38 & Ortalama & 8.12 & 2.74 & 18.39 \\
\hline
\end{tabular}

Üst Toprak: 0-30 cm Toprak Derinliği; Alt Toprak: 30-60 cm Toprak Derinliği 
Çizelge 4. Topraklarda Toplam Ağır Metal ve Kükürt Konsantrasyonları (mg kg-1) ile Sapma ve $\beta$ Değerleri ve Mesafe Arasındaki llișkiler

Table 4. Relationships Between Total Heavy Metal and Sulfur Concentrations ( $\mathrm{mg} \mathrm{kg}^{\prime}$ ), and Deviation and $\beta$ Values, and Distance

\begin{tabular}{cccccccccc}
\hline \multicolumn{7}{c}{ Toprakların farklı derinliklerinde toplam ağır metal ve S içerikleri $\left(\mathrm{mg} \mathrm{kg}^{-1}\right)$} \\
\hline $\begin{array}{c}\text { Derinlik } \\
(\mathrm{cm})\end{array}$ & & $\mathrm{Cd}$ & $\mathrm{Cr}$ & $\mathrm{Cu}$ & $\mathrm{Ni}$ & $\mathrm{Pb}$ & $\mathrm{Zn}$ & As & $\mathrm{S}$ \\
\hline \multirow{3}{*}{$0-30$} & Min. & 0.6 & 117.5 & 23.9 & 120.5 & 0.3 & 124 & 1.3 & 320 \\
& Max. & 1.1 & 311.6 & 46.8 & 469.1 & 0.9 & 252.3 & 2.5 & 1360 \\
& Ort. & 0.89 & 194.8 & 36.7 & 285.1 & 0.7 & 178.8 & 1.9 & 508.5 \\
\hline \multirow{3}{*}{$30-60$} & Min. & 0.6 & 118.8 & 28.6 & 116.5 & 0.4 & 110.1 & 1.2 & 320 \\
& Max. & 1.1 & 294.7 & 45 & 455.2 & 1.2 & 238.4 & 2.3 & 720 \\
& Ort. & 0.88 & 179.6 & 35.6 & 241.4 & 0.8 & 150.0 & 1.9 & 437.1 \\
\hline
\end{tabular}

Ölçüm değerlerinin referans değerlerle karșılaștırılması ile elde edilen sapma değerleri

\begin{tabular}{|c|c|c|c|c|c|c|c|c|c|}
\hline \multirow{3}{*}{$0-30$} & Min. & 0.69 & 0.72 & 0.67 & 0.52 & 0.39 & 0.82 & 0.40 & $-\star$ \\
\hline & Max. & 1.21 & 1.9 & 1.31 & 2.02 & 1.33 & 1.67 & 1.95 & $-*$ \\
\hline & Ort. & 1.00 & 1.16 & 1.02 & 1.21 & 0.96 & 1.15 & 0.61 & $-{ }^{*}$ \\
\hline \multirow{3}{*}{$30-60$} & Min. & 0.78 & 0.73 & 0.84 & 0.5 & 0.65 & 0.73 & 0.73 & $-{ }^{\star}$ \\
\hline & Max. & 1.35 & 1.8 & 1.32 & 1.95 & 1.83 & 1.57 & 1.37 & $-*$ \\
\hline & Ort. & 1.06 & 1.08 & 1.06 & 1.04 & 1.22 & 1.06 & 1.12 & $-*$ \\
\hline \multicolumn{10}{|c|}{ Katılım-kayıp oranı ilișkilerinden elde edilen $\beta$ değerleri } \\
\hline \multicolumn{2}{|c|}{ En yakın(Mesafe) } & 1.14 & 0.72 & 1.11 & 1.02 & 1.04 & 1.04 & 1.05 & 1.50 \\
\hline \multicolumn{2}{|c|}{ En uzak(Mesafe) } & 1.36 & 1.82 & 1.63 & 1.59 & 0.92 & 1.90 & 1.60 & 2.03 \\
\hline \multicolumn{2}{|c|}{ Ort. } & 1.11 & 1.13 & 1.13 & 1.25 & 0.88 & 1.19 & 1.11 & 1.08 \\
\hline \multicolumn{10}{|c|}{ Ağır Metal konsantrasyonlar ve mesafe arasındaki ilișkiler } \\
\hline \multicolumn{2}{|c|}{$R^{* *}$} & 0.028 & 0.263 & 0.152 & 0.217 & 0.366 & 0.304 & 0.156 & $-*$ \\
\hline \multicolumn{2}{|c|}{$n^{* * *}$} & 15 & 15 & 15 & 15 & 15 & 15 & 15 & $-^{*}$ \\
\hline
\end{tabular}

*Ölçümlenmemiștir, * *Regresyon analizi sonucu elde edilen çoklu R değerleri, ** *Çalıșllan nokta sayısı

karșılaștırılması sonucu elde edilen ortalama sapma değerleri ise üst ve alt toprak derinliklerinde, sırasıyla 1.0 ve 1.06 olarak belirlenmiștir. Toprak Kirliliğinin Kontrolü ve Noktasal Kaynaklı Kirlenmiș Sahalara Dair Yönetmelikte (TKKY) sapma değeri $\leq 1$ olması durumunda, takip gerektirmeyen saha (kirlenmemiș saha) olarak değerlendirilmektedir (Anonim, 2010). Bölge toprakları hafif alkalin özellikte olup, kireç içeriği \%15'in üzerindedir. Yüksek $\mathrm{pH}$ ve kireç içeren topraklarda, $\mathrm{Cd}$ çökelerek veya kireç ile reaksiyona girerek bitkiler tarafından alınamaz konuma dönüșmektedir (Hasemi, 1996).

Katılım-kayıp oranın hesaplamasından elde edilen $\beta$ faktörü açısından bakıldığında, fabrikaya en yakın noktada alınan toprak örneğinin $\beta$ faktörlerinin 1.14, en uzak olan değerin 1.36 olduğu, alan ortalamasının ise 1.11 olduğu, fabrikaya uzaklık ile ölçülen konsantrasyonlar arasında önemli istatistiksel bir ilișki bulunmadığı $(r=0.028)$ dikkate alındığında, $C d$ yönünden alana dıșarıdan bir katıımın olduğu söylenemez.

Krom: Araștırma alanı topraklarının üst ve alt toprak derinliklerinde toplam $\mathrm{Cr}$ içerikleri sırasıyla 117.5 - 311.6 ve $118.8-294.7 \mathrm{mg} \mathrm{kg}^{-1}$ arasında değișmektedir. Topraklarda ölçüm değerlerinin referans değerlerle karșılaștırılması sonucu elde edilen ortalama sapma değerleri ise üst ve alt toprak derinliklerinde, sırasıyla 1.16 ve 1.08 olarak belirlenmiștir. TKKY'a göre sapma değeri > 1 olması durumunda, ikinci așama değerlendirme sürecine tabi takip gerektiren 
saha olarak değerlendirilmektedir (Anonim, 2010). Toprakların toplam $\mathrm{Cr}$ içeriği hafif kumlu topraklarda 2-350, orta tınlı ve siltli topraklarda 10-300, tınlı topraklarda 30-1100, kalkerli topraklarda 5-150 mg kg-1 arasında değiștiği rapor edilmiștir (Kabata-Pendias ve Mukherjee, 2007). Genel olarak, toprakların toplam Cr içeriği ortalama $54 \mathrm{mg} \mathrm{kg}^{-1}$ dolaylarındadır (Bowen, 1979; Sposito, 1989). Toprakların oluștuğu kayaçların mafik ve ultramafik kayaçlar olması, yine serpantin ve ofiyolitlerin baskın olduğu alanlarda olușan topraklarda $\mathrm{Cr}$ içeriğinin yüksek olduğu bildirilmiștir (Kabata-Pendias ve Mukherjee, 2007). Kahramanmarașin doğu bölgesinde dolomit, kireçtașı, ofiyolit, serpantin, gabro, dunit gibi kayaçların baskın ve $\mathrm{Cr}$ içeriklerinin yüksek (281$1567 \mathrm{mg} \mathrm{kg}^{-1}$ ) olduğu tespit edilmiștir (Bağcı, 2013). Bu nedenle, bölgede toprakların Cr içeriğinin normal topraklara göre yüksek olması, toprak olușturan kayaçlar ve ana materyal ile ilișkili olma olasılığını artırmaktadır.

Katılım-kayıp oranın hesaplamasından elde edilen $\beta$ faktörü açısından bakıldığında, $\mathrm{Cr}$ konsantrasyonlarındaki yüksekliğin kaynağının ana materyal mi yoksa dıșarıdan bir katılımın mı olduğunu belirlemek amacı ile genetiksel oranlar incelendiğinde, bunun ana materyalden geldiği görülmüștür. Alanın alüviyal olması ve bölgede serpantin ana materyalinin fazla bulunması bu yüksekliğin nedeni olarak değerlendirilmiștir. Fabrikaya en yakın noktada alınan toprak örneğinin $\beta$ faktörlerinin 0.72 , en uzak olan değerin 1.82 olduğu, alan ortalamasının ise 1.13 olduğu, fabrikaya uzaklık ile ölçülen konsantrasyonlar arasında önemli istatistiksel bir ilișki bulunmadığı $(r=0.263)$ dikkate alındığında krom yönünden alana dıșarıdan bir katılımın olduğu söylenemez.

Bakır: Araștırma alanı topraklarının üst ve alt derinliklerinin $\mathrm{Cu}$ içerikleri sırasıyla 23.9- 46.8 ve 28.6- $45.0 \mathrm{mg} \mathrm{kg}^{-1}$ arasında değișmektedir. Toprakların üst ve alt derinliklerinde, ölçüm değerlerinin referans değerlerle karșılaștırılması sonucu elde edilen ortalama sapma değerleri sırasıyla 1.02 ve 1.06'dır. Burada alt toprağın sapma değerinin üst topraktan daha fazla olduğu görülmektedir. Bu durum toprakların Cu içerinin ana materyal ile ilișkili olduğunu yansıtmaktadır. Ülkemizde farklı bölgelerde yapılan araștırmalarda toprakların toplam Cu içeriği 35.6-98.8 mg kg-1' arasında bulunmuștur (Aydınalp ve Cresser, 2003;
Kızılkaya vd., 1997). İnceleme yapılan toprakların Cu içeriği ile ilgili yönetmelikte verilen sapma değerleri dikkate alındığında șu an toprakların Cu içeriğinin risk olușturmadığı yargısına varılabilir.

Katılım-kayıp oranın hesaplamasından elde edilen $\beta$ faktörü açısından bakıldığında, fabrikaya en yakın noktada alınan toprak örneğinin $\beta$ faktörlerinin 1.11, en uzak olan değerin 1.63 olduğu, alan ortalamasının ise 1.13 olduğu, fabrikaya uzaklık ile ölçülen konsantrasyonlar arasında önemli istatistiksel bir ilișki bulunmadığı ( $r=0.152)$ dikkate alındığında bakır yönünden alana dıșarıdan bir katılımın olduğu söylenemez.

Nikel: Araștırma alanı toprakların üst ve alt toprak derinliklerindeki toplam $\mathrm{Ni}$ içerikleri sırasılyla 120.5 - 469.1 ve 116.5 - 455.2 mg $\mathrm{kg}^{-1}$ arasında bulunmustur. Toprakların üst ve alt toprak derinliklerinde toplam Ni'in ölçüm değerlerinin referans değerlerle karșılaștırılması sonucu elde edilen ortalama sapma değerleri sırasıyla 1.21 ve 1.04'dür. TKKY'a göre sapma değeri > 1 olması durumunda, ikinci așama değerlendirme sürecine tabi takip gerektiren saha olarak değerlendirilmektedir (Anonim, 2010). Bölge topraklarının Ni içeriğinin hem üst, hem de alt toprak derinliğinde genel olarak yüksek olması, toprak olușturan kayaçlar ve ana materyal ile ilișkili olduğu kanaatini uyandırmaktadır. Araștırma bölgesinin jeolojik yapısı konusunda yapılan araștırmalarda, bölgede $\mathrm{Ni}$ içeriği yüksek ultra bazik materyallerin olduğunu ve bu materyalin Ni içeriğinin 25-226 mg kg-1 arasında değiștiği belirlenmiștir (Bağcl, 2013). Kabata-Pendias ve Mukherjee (2007), toprakların Ni içeriğinin 0.2-450 mg kg-1' gibi çok geniș sınırlar içerinde değiștiğini, așırı bazik ve volkanik kayaçlardan olușan toprakların doğal olarak Ni içeriğinin yüksek olduğunu, özellikle serpantin kayaçlarının olduğu alanda olușan topraklarda toplam Ni içeriğinin 770-7335 mg kg-1 arasında değișim gösterdiğini bildirmiștir.

Katılım-kayıp oranın hesaplamasından elde edilen $\beta$ faktörü açısından bakıldığında, fabrikaya en yakın noktada alınan toprak örneğinin $\beta$ faktörlerinin 1.02, en uzak olan değerin 1.59 olduğu, alan ortalamasının ise 1.25 olduğu, fabrikaya uzaklık ile ölçülen konsantrasyonlar arasında önemli istatistiksel bir ilișki bulunmadığı ( $r=0.217)$ dikkate alındığında, nikel yönünden alana dıșarıdan bir katıımın olduğu söylenemez. 
Kurșun: Araștırma alanı toprakların üst ve alt toprak derinliklerinde toplam $\mathrm{Pb}$ içerikleri sırasıyla $0.3-0.9$ ve $0.4-0.2 \mathrm{mg} \mathrm{kg}^{-1}$ arasında değișmektedir. Toprakların üst ve alt toprak derinliklerinde toplam Pb'un ölçüm değerlerinin referans değerlerle karșılaștırılması sonucu elde edilen ortalama sapma değerleri sırasıyla 0.96 ve 1.22 dir. Alt toprağın sapma değerinin üst topraktan fazla olması, dıșarıdan kirletici olarak Pb ilavesi olmadığını yansıtmaktadır. Toprakların toplam kurșun içeriği genel olarak 2-200 mg kg-1 arasında değișmekte olup tipik değer $19 \mathrm{mg} \mathrm{kg}^{-1}$ dir (Bowen, 1979; Sposito, 1989). Bu nedenle inceleme alanı topraklarında çevresel ve tarımsal açıdan șu an Pb kirliliği yoktur.

Katılım-kayıp oranın hesaplamasından elde edilen $\beta$ faktörü açısından bakıldığında, fabrikaya en yakın noktada alınan toprak örneğinin $\beta$ faktörlerinin 1.04, en uzak olan değerin 0.92 olduğu, alan ortalamasının ise 0.88 olduğu, fabrikaya uzaklık ile ölçülen konsantrasyonlar arasında önemli istatistiksel bir ilișki bulunmadığı ( $r=0.366)$ dikkate alındığında, kurșun yönünden alana dıșarıdan bir katıımın olduğu söylenemez.

Çinko: Araștırma alanı toprakların üst ve alt toprak derinliklerinde toplam Zn içeriği sırasıyla 178.8 ve $150 \mathrm{mg} \mathrm{kg}^{-1}$ bulunmuștur. Ölçüm değerlerinin referans değerlerle karșılaștııılması sonucu sapma değerleri sırasıyla 1.15 ve 1.06 bulunmuștur. TKKY'a göre sapma değeri > 1 olması durumunda, ikinci așama değerlendirme sürecine tabi takip gerektiren saha olarak değerlendirilmektedir (Anonim, 2010). Genel olarak, topraklarda Zn'nun kimyasal sorpsiyonu toprakların $\mathrm{pH}$, kireç, metal oksitler, kil içerikleri ve tipleri gibi temel özelliklere bağlıdır. Yüksek pH, kireç içeren topraklarda toplam Zn yüksek olsa da bitkiler tarafından alınabilir Zn konsantrasyonu düșük çıkmaktadır.

Katılım-kayıp oranın hesaplamasından elde edilen $\beta$ faktörü açısından bakıldığında, fabrikaya en yakın noktada alınan toprak örneğinin $\beta$ faktörlerinin 1.04, en uzak olan değerin 1.90 olduğu, alan ortalamasının ise 1.19 olduğu, fabrikaya uzaklık ile ölçülen konsantrasyonlar arasında önemli istatistiksel bir ilișki bulunmadığı ( $r=0.304$ ) dikkate alındığında çinko yönünden alana dıșarıdan bir katılımın olduğu söylenemez.
Arsenik: Araștırma alanı topraklarının üst ve alt toprak derinliklerinde toplam ortalama As içeriği her iki derinlikte de $1.90 \mathrm{mg} \mathrm{kg}^{-1}$ bulunmuștur. Ölçüm değerlerinin referans değerlerle karșılaștırılması sonucu sapma değerleri 0.401.95 ve 0.73-1.37 arasında değișmektedir. Toprakların As içeriği değerlendirildiğinde en yüksek As değeri fabrikaya en uzak olan toprağın üst katmanında saptanmıștır. Bu yüksek As düzeyinin toprağı olușturan ana materyal ve bitki koruma amaçlı kullanılan pestisit ve herbisitlerden kaynaklı olabileceği düșüncesini olușturmaktadır. As ile ilgili yapılan araștırmalarda genel olarak toprakların toplam As içeriğinin 0.1-40 mg $\mathrm{kg}^{-1}$ arasında değiștiği ve ortalama $5 \mathrm{mg} \mathrm{kg}^{-1}$ olduğu rapor edilmiștir (Sposito, 1989; KabataPendias ve Mukherjee, 2007). Tarım alanlarında genellikle As, kullanılan pestisit ve herbisitlerden kaynaklanmaktadır. Avrupa'da endüstriyel bölgelerde As içeriğinin 100-115 mg kg-1 kadar yükselerek kirlilik olușturduğu rapor edilmiștir (Göd ve Heiss, 1996).

Katılım-kayıp oranın hesaplamasından elde edilen $\beta$ faktörü açısından bakıldığında, fabrikaya en yakın noktada alınan toprak örneğinin $\beta$ faktörlerinin 1.05, en uzak olan değerin 1.60 olduğu, alan ortalamasının ise 1.11 olduğu, fabrikaya uzaklık ile ölçülen konsantrasyonlar arasında önemli istatistiksel bir ilișki bulunmadığı $(r=0.156)$ dikkate alındığında, arsenik yönünden alana dıșarıdan bir katılımın olduğu söylenemez.

Kükürt: Araștırma alanı topraklarının üst toprak derinliğinde toprakların toplam S içeriği $320-1360 \mathrm{mg} \mathrm{kg}^{-1}$, alt toprak derinliğinde ise 320-720 $\mathrm{mg} \mathrm{kg}^{-1}$ arasında değișmektedir. Genel olarak topraklarda toplam S içeriği 1600 mg $\mathrm{kg}^{-1}$ olarak belirtilmiștir (Sposito, 1989). Incelen alanın topraklarının $\mathrm{pH}$ değeri 8'den büyüktür. Genel olarak bitkilerin optimum pH istekleri 6.57.0'dır. Katıım-kayıp oranın hesaplamasından elde edilen $\beta$ faktörü açısından bakıldığında, fabrikaya en yakın noktada alınan toprak örneğinin $\beta$ faktörünün 1.50 , en uzak olan değerin 2.03 olduğu, alan ortalamasının ise 1.08 olduğu, fabrikaya uzaklık ile ölçülen konsantrasyonlar arasında önemli istatistiksel bir ilișki bulunmadığı ( $r=0.363$ ) dikkate alındığında kükürt yönünden alana dıșarıdan bir katılımın olduğu söylenemez. 


\section{Sonuçlar}

Bu çalıșmada, Kahramanmaraș-Narlı Ovasında güney doğu kıyısında bulunan çimento fabrikasının çevresindeki tarımsal alanlardan alınan toprak örneklerinde fabrika kaynaklı bir elementel kirlilik olup olmadığı araștırılmıștır. Topraklarda yapılan toplam elementel analiz sonuçlarından elde edilen Sapma değerleri ve Katılım-Kayıp oranlarının ( $\beta$ faktörleri) genellikle 1 civarında olduğu ve sapma değerleri ile katııımkayıp oranlarının çimento fabrikasına uzaklık ve yakınlığa bağlı olarak önemli bir değișkenlik göstermediği saptanmıștır. Elde edilen verilere göre, bölgede hakim rüzgarların fabrika emisyonlarının tarım alanlarına tașınmasına yardımcı olmadığı, incelenen elementlerin ana materyal ve doğal olaylara bağlı olarak oluștuğu ve toprak olușum süreçlerinin yansımasının bir sonucu olduğu görülmüștür. Analitik ve moleküler katılım-kayıp ve sapma değerlerinin yorumlanmasından, toprak örneklerinin alındığı tarih itibariyle, alana dıșarıdan bir katıımın olmadığı sonucuna ulașılmıștır.

\section{KAYNAKLAR}

Abeln DL, Hastings RJ, Scxhreiber R, Yonley C (1993). Detailed Illustration of Contingent Management Practices for Cement Kiln Dust. In: Research and Development Bulletin, SP1 15T. Skokie (IL): Portland Cement Association.

Anonim (2010). Toprak Kirliliği Kontrulü ve Noktasal Kaynaklı Kirlenmiș Sahalara Dair Yönetmenlik. Resmi Gazete. 08.06.2010, sayı: 27605.

Aydınalp C, Cresser MS (2003). The Background Levels of Heavy Metals in Vertisols Under Mediterranean Type of Climate in the Region of Turkey. Journal of Central European Agriculture: 289-296.

Bağcı U (2013). The Geochemistry and Petrology of the Ophiolitic Rocks from the Kahramanmaraș Region, Southern Turkey. Turkish J. Earth Sci.

Black CA (1965). Methods of Analysis Agreon., No: 9, Ame. Soc. Agr., Madison Wisconsin. USA.

Bowen HJ (1979). Environmental Chemistry of the Elements. London: Academic Pres.

Efe E, Bek Y, Șahin M (2000). SPSS'te Çözümleri ile İstatistik Yöntemler II. Kahramanmaraș: KSÜ.

Gül Ki (2011). Birden Fazla Metal ile Kirlenmiș Topraklarda Ayçiçeği ve Mısırın Fitoekstraksiyonu Üzerine EDTA ve DTPA'nın Etkisi. Ankara Üniversitesi, Fen Bilimleri Enstitüsü Doktora Tezi.

Gülçur F (1974). Toprağın Fiziksel ve Kimyasal Analiz Metodları, İstanbul Üniversitesi Orman Fakültesi Yayınları, Yayın No: 201, Kutulmuș Matbaası, İstanbul.
Gündoğan R (1998). Land Use Interpretations at the Taxonomic Category Level for Kahramanmaraș Province, Turkey. Proceedings of Int. Sym. on Arid Region Soils, (Ed. Yeșilsoy, M.Ș.). Menemen-İzmir, Turkey.

Göd R, Heiss G (1996). Die Arsenanomalie Feistriz am Wechsel. Jahrb Geol Bundesanstalt, 437-444.

Hasemi E (1996). Toprakta ve Bitkideki Cd Miktarları. Doktora Tezi, Ankara Üniversitesi, Fen Bilimleri Enstitüsü.

Hossner LR (1996). Dissolution for Total Elemental Analysis. 3rd Edition. Methods of Soil Analysis. Part 3, Chemical Methods, D.L. Sparks, 46-64. Madison, WI: Soil Science Society of America and American Society of Agronomy.

Ișıklı B, Demir TA, Akar T, Berber A, Urer SM, Kalyoncu C, Canbek M (2006). Cadmium Exposure from the Cement Dust Emissions: A Field Study in a Rural Residence. Chemosphere, 63 (9): 1546-52.

Jenny H (1967). Origin of Soils. In Applied Sedimentation. (Ed by Parker D Trask), p. 41-61, John Wiley \& Sons, New York.

Haktanır K, Arcak S (1998). CCevre Kirliliği. Ankara Üniversitesi Ziraat Fakültesi. Yayın No:1503.

Kabata-Pendias A ve Mukherjee AB (2007). Trace Elements from Soil to Human. Berlin: Springer-Verlag.

K.Maraș Meteoroloji İstasyonu Müdürlüğü (2018a). Meteorolojik Veri Grafiği-Kahramanmaraș İli Uzun Yıllara Göre Hakim Rüzgar Yönü.

K.Maraș Meteoroloji İstasyonu Müdürlüğü (2018b) Meteorolojik Veri Grafiği-Kahramanmaraș İli Aylık Ortalama Sıcaklık Değerleri.

Karaca F, Alagha O, Elçi E, Ertürk F, Yılmaz YZ, Özkara T (2006). Büyükçekmece Gölü Havzasında Havanın PM2,5 ve PM2,5-10 Gruplarında Krom Derișimleri. Ekoloji:15(61), 1621.

Khamparia A, Chattergee SK, Sharma GD (2012). Assessment on Effect of Cement Dust Pollution on Soil Health. Journal of Environmental Research and Development, 7(1):368-374.

Khashman OA, Shawabkeh RA (2006). Metal Distribution in Soils Around the Cement Factory in Southern Jordan. Environmental Pollution: 387-394.

Kızılkaya R, Karaca A, Arcak S (1997). Samsun yöresi topraklarında $\mathrm{Zn/Cd}$ oranı ve bu oran ile İz Element ve Ağır Metaller (Fe, Cu, Mn, Pb, Ni) Arasındaki İlișkiler. I. Ulusal Çinko Kongresi, 12-16 Mayıs 1997. Eskișehir, 501-509.

Korkmaz H (2001). Kahraman Maraș Havzasının Jeomorfolojisi. Cilt ì Kültür Müdürlüğü Yayınları No:3. Kahramanmaraș: Kahramanmaraș Valiliği.

Maina HM, Egila JN, Nkafamiya II, Shagal MH (2013). Impact of Cement Dust Deposition on the Elemental Composition of Soils in the Vicinity of Ashaka Cement Factory, Nigeria. International Research Journal of Agricultural science and Soil Science 3(2), 66-74. 
Mandal A, Voutchkov M (2011). Heavy Metals in Soils Around the Cement Factory in Rockfort. International Journal of Geosciences:48-54.

Richards, L.A., 1954. Diagnosis and Improvement of Saline and Alkaline Soils, USA, Salinity Labrotary, s. 60.

Sayın M (2011). Toprak Mineralojisi Kitabı. Çukurova Üniversitesi Ziraat Fakültesi Ofset Atölyesi Genel Yayın No:227, Ders Kitapları Yayın No: A-72, Adana, Türkiye.

Somogyi A, Braun M, Posta J (1997). Comparison Between X-ray Fluorescence and Inductively Coupled Plasma Atomic Emission Spectrometry in the Analysis of Sediment Samples. Spectrochimica Acta Part B, p. 2011 2017.
Sposito G (1989). Chemistry of Soils. New York: Oxford University Pres, Inc., 1989.

Uysal i, Müftüoğlu NM, Demirer T, Karabacak E, Tütenocaklı T (2006). Çanakkale'de Çimento Tozlarının Bazı Bitkilere ve Topraklara Etkileri. Ege Üniv. Ziraat Fak. Dergisi, 43(2):133-144.

Yılmaz K (1990). Harran Ovası Topraklarının Mineralojik Karakterizasyonları. Doktora Tezi. Çukurova Üniversitesi, Fen Bilimleri Enstitüsü, Adana. 